\title{
Shear investigation of self compacted concrete at different shapes
}

\author{
Ali F. Atshan ${ }^{1}$, Kamal Sh. Mahmoud ${ }^{2}$, Ahmed H. Abed ${ }^{2}$ \\ ${ }^{1} \mathrm{Al} \_$Mustansiriya University, College of Engineering, Environmental Engineering Department. \\ ${ }^{2} \mathrm{Al} \_$Mustansiriya University, College of Engineering, Civil Engineering Department.
}

Rec. 24 Aug, 2014 Accept. 25 Sept, 2014

\begin{abstract}
Twenty seven self-compacted concrete (SCC) beams at different shaped were designed and tested to determine the effect of using SCC on the shear strength under two concentrated loads. The tested beams were divided into three groups according to the shape of the section rectangular sections, T-sections and I-sections. Each group was divided into three series, according to the clear San to the effective depth ratio ( $\mathrm{Ln} / \mathrm{d}$ ). Each series beams have the same longitudinal steel ratio, cross section area and clear span to effective depth ratio, but have different values in compressive strength $\left(f_{c}^{\prime}\right)$.It was found that The ultimate shear strength predicated from ACI $318 \mathrm{M}-11$ is conservative prediction than the experimental values, The ultimate shear strength of SCC rectangular beams increase about $16.5 \% .35 .245 \%$ and $25.665 \%$ when the compressive strength increased from (29.36 to $49.2 \mathrm{MPa}$ ) at clear span to effective ratio (ln/d) 5.84, 5.5 and 5.05 respectively, The ultimate shear strength of SCC T-beams increase about 28.57\%.10.714\%and $10.17 \%$ when the compressive strength increased from (29.36 to $49.2 \mathrm{MPa}$ ) at clear span to effective ratio $(\ln / \mathrm{d}) 5.84,5.5$ and 5.05 respectively, while The ultimate shear strength of SCC Ibeams increase about $14.38 \% .15 .55 \%$ and $10.746 \%$ when the compressive strength increased from $(29.36$ to $49.2 \mathrm{MPa}$ ) at clear span to effective ratio $(\mathrm{ln} / \mathrm{d}) 5.84,5.5$ and 5.05 respectively. The clear span to the effective depth ratio $(\mathrm{ln} / \mathrm{d})$ has a significant influences on the ultimate shear strength of SCC beams, The ultimate shear strength of SCC rectangular beams increased about $21.58 \%, 32.9 \%$ and $32.01 \%$ when the clear span to the effective depth $(\mathrm{ln} / \mathrm{d})$ decreased from (5.84 to 5.05) at compressive strength $\left(f_{c}^{\prime}\right) 29.36,41.42$ and 49.2 MPa respectively, The ultimate shear strength of SCC T-beams increased about $40.47 \%, 34.73 \%$ and $20.37 \%$ when the clear span to the effective depth $(\ln / \mathrm{d})$ decreased from (5.84 to 5.05) at compressive strength $\left(f_{c}^{\prime}\right) 29.36,41.42$ and $49.2 \mathrm{MPa}$ respectively, while The ultimate shear strength of SCC I-beams increased about $44.72 \%, 45.19 \%$ and $40.13 \%$ when the clear span to the effective depth $(\ln / \mathrm{d})$ decreased from $(5.84$ to 5.05) at compressive strength $\left(f_{c}^{\prime}\right) 29.36,41.42$ and $49.2 \mathrm{MPa}$ respectively.
\end{abstract}

Keywords: shear strength, rectangular section, I-section, T-section, self-compacted concrete.

\section{Introduction:}

Self-Compacted concrete (SCC), is a new kind of high performance concrete (HPC) with very effective deformability and segregation resistance. The main advantage of SCC is; a flowing concrete without segregation and bleeding, capable of filling spaces in dense reinforcement or inaccessible voids without hindrance or blockage. The composition of SCC should be designed in order not to separate and not to excessively bleed. Concrete strength development is determined not only by the water-to-cement ratio, but also by the content and specification of mix materials. (Bin MUDA, M.F., 2009).

\section{Research significance:}

Concrete has been used in the construction industry for centuries. Many modifications and developments have been made to improve the performance of concrete, especially in term of strength and workability. Engineers have found new technology of concrete called self-compacted concrete. The main objective of the work described in this study is to

* Corresponding author: 39

$凶$ afarhan400@yahoo.com 
investigate and to get more information and more understanding about the shear strength of self-compacted concrete beams at different shapes.

\section{Tested program}

\section{Description of specimens:}

The tested beams were divided into three groups according to the shape of the section rectangular sections, T-sections and I-sections. The first group consist rectangle has an overall length (952, 903 and $837 \mathrm{~mm}$ ). The cross section has overall dimension of $100 \mathrm{~mm}$ (width of beams) by $170 \mathrm{~mm}$ (total depth). The longitudinal steel reinforcement consist of six bar (diameter of the bar $8 \mathrm{~mm}$, with area of $50.265 \mathrm{~mm}^{2}$ ) laid in two layer at the bottom and two bar (diameter $4 \mathrm{~mm}$, area of 12.566 $\mathrm{mm}^{2}$ ) laid in one layer at the top. The internal steel stirrups are $4 \mathrm{~mm}$ in diameter (12.566 $\mathrm{mm}^{2}$ ) at spacing $73 \mathrm{~mm}$ center to center as shown in Fig.(1), the second group consist of $\mathrm{T}$-sections has overall length the overall length(1140, 1080 and 1000) $\mathrm{mm}$ long. The Tsection has overall dimensions of $220 \mathrm{~mm}$ (width of flange) by $200 \mathrm{~mm}$ (total depth). The thickness of web is (60) $\mathrm{mm}$ and the thickness of flange is (50) $\mathrm{mm}$. The longitudinal deformed steel reinforcement consist of four bars of $8 \mathrm{~mm}$ diameter laid in two layer at the bottom and four plane bars of $4 \mathrm{~mm}$ diameter laid in one layer at the top. The internal steel stirrups are $4 \mathrm{~mm}$ in diameter spaced of 89 $\mathrm{mm}$ center to center as shown in Fig.(2), while the third group consist of I-sections has overall the overall length of (1443, 1365 and 1265) $\mathrm{mm}$. The cross section has overall dimension of $250 \mathrm{~mm}$ total depth and width of flange 200 $\mathrm{mm}$. The longitudinal steel reinforcement consists of four bars $(8 \mathrm{~mm}$ diameter of the bar, area of $(50.265 \mathrm{~mm} 2)$ lay in one layer at the bottom and four bars (4 mm diameter, area of $(12.566 \mathrm{~mm} 2)$ laid in one layer at the top. The internal steel stirrups are $(4 \mathrm{~mm})$ in diameter $\left(12.566 \mathrm{~mm}^{2}\right)$ at spacing $115 \mathrm{~mm}$ center to center as shown in fig.(3).the total description of the beams which used in this study are listed in Tables (1) and the test setup is shown in fig. (4).

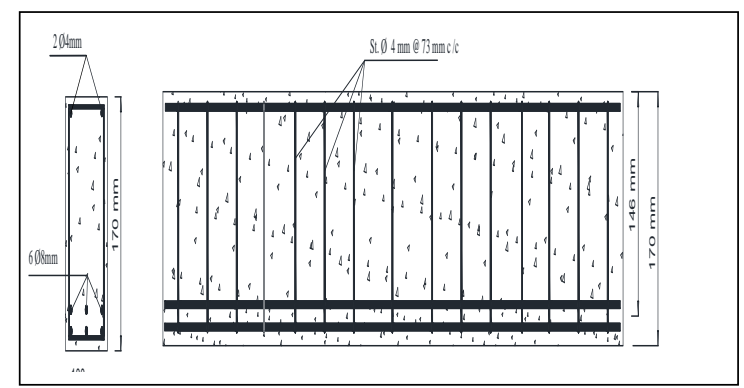

Fig. (1): Details of rectangular section all dimensions in $\mathrm{mm}$.

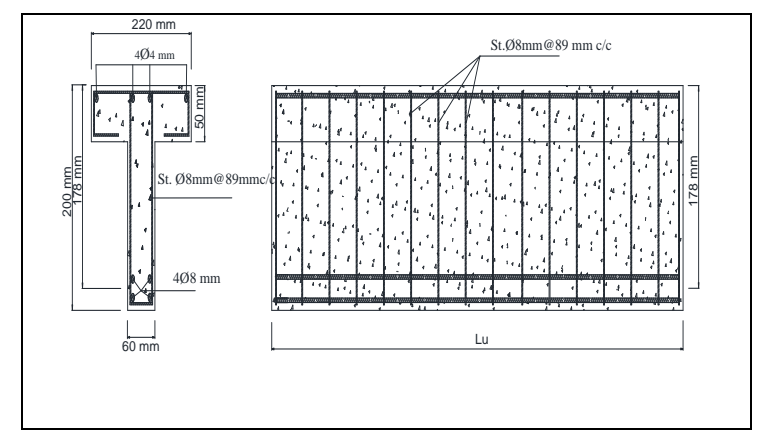

Fig. (2): Details of T-section all dimensions in $\mathrm{mm}$.

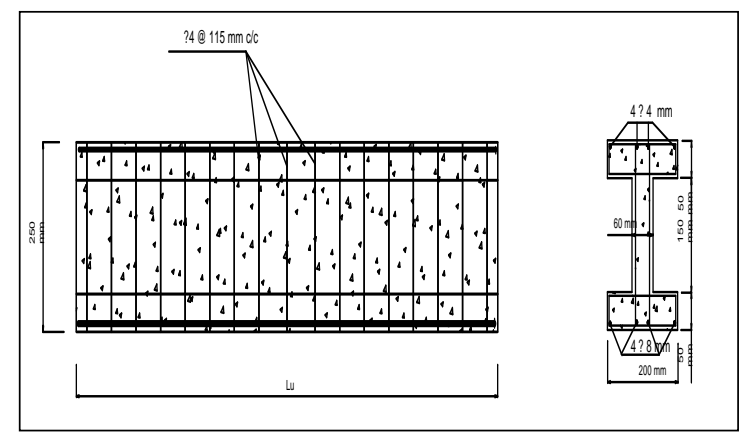

Fig. (3): Details of I-section all dimensions in $\mathrm{mm}$.

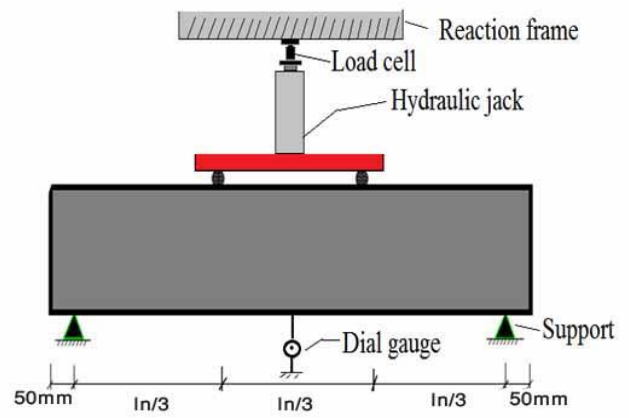

Fig. (4): Schematic diagram of test set-up. 


\begin{tabular}{|c|c|c|c|c|c|}
\hline Shapes & Beam & $\begin{array}{c}\text { Comp. strength }\left(f_{c}^{\prime}\right) \\
\mathbf{M P a}\end{array}$ & $\begin{array}{c}\text { Clear span (ln) } \\
\text { mm }\end{array}$ & $\begin{array}{l}\text { Effective depth } \\
\text { (d) } \mathrm{mm}\end{array}$ & $\begin{array}{l}\text { Clear span to effective } \\
\text { depth ratio }(\ln / d)\end{array}$ \\
\hline \multirow{9}{*}{$\begin{array}{l}\text { Rectangular } \\
\text { Section }\end{array}$} & A 1 & 29.39 & 852 & 146 & 5.84 \\
\hline & A 2 & 29.39 & 803 & 146 & 5.50 \\
\hline & A 3 & 29.39 & 737 & 146 & 5.05 \\
\hline & B 1 & 41.4 & 852 & 146 & 5.84 \\
\hline & B 2 & 41.4 & 803 & 146 & 5.50 \\
\hline & B 3 & 41.4 & 737 & 146 & 5.05 \\
\hline & C 1 & 49.2 & 852 & 146 & 5.84 \\
\hline & C 2 & 49.2 & 803 & 146 & 5.50 \\
\hline & C 3 & 49.2 & 737 & 146 & 5.05 \\
\hline \multirow{9}{*}{ T-Section } & A 10 & 29.39 & 1040 & 178 & 5.84 \\
\hline & A 20 & 29.39 & 980 & 178 & 5.50 \\
\hline & A 30 & 29.39 & 900 & 178 & 5.05 \\
\hline & B 10 & 41.4 & 1040 & 178 & 5.84 \\
\hline & B 20 & 41.4 & 980 & 178 & 5.50 \\
\hline & B 30 & 41.4 & 900 & 178 & 5.05 \\
\hline & C 10 & 49.2 & 1040 & 178 & 5.84 \\
\hline & C 20 & 49.2 & 980 & 178 & 5.50 \\
\hline & C 30 & 49.2 & 900 & 178 & 5.05 \\
\hline \multirow{9}{*}{ I-Section } & A 100 & 29.39 & 1343 & 230 & 5.84 \\
\hline & A 200 & 29.39 & 1265 & 230 & 5.50 \\
\hline & A 300 & 29.39 & 1162 & 230 & 5.05 \\
\hline & B 100 & 41.4 & 1343 & 230 & 5.84 \\
\hline & B 200 & 41.4 & 1265 & 230 & 5.50 \\
\hline & B 300 & 41.4 & 1162 & 230 & 5.05 \\
\hline & C 100 & 49.2 & 1343 & 230 & 5.84 \\
\hline & C 200 & 49.2 & 1265 & 230 & 5.50 \\
\hline & C 300 & 49.2 & 1162 & 230 & 5.05 \\
\hline
\end{tabular}

Table (1): Total description of the tested beams.

Materials:

General description and specification of materials used in the tested beams are listed below; tests are made in the National Center for Constriction Laboratories and Research

- Cement: Ordinary Portland cement type I produced at the northern cement factory (Tasluja-Bazian) is used throughout this investigation which conforms to the Iraqi

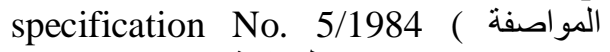
(العر اقية رقم (0) ع (9)), Tables (2) and (3) show the chemical and physical properties of the cement used

- Fine Aggregate: Al-Ukhaider natural sand is used. This complies with the Iraqi

Standard Specification No.45/1984, zone (2). The specific gravity, sulfate contents $\left(\mathrm{SO}_{3}\right)$ and absorption of the used sand was 2.66, $0.4 \%, 1.7 \%$ respectively.
- Coarse Aggregate: Crushed gravels maximum sizes $10 \mathrm{~mm}$ from the $\mathrm{Al}$ Nibaee area are used in this study. This complies with the Iraqi Standard

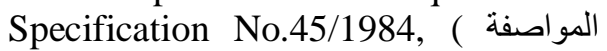
(العراقية رقم (191). The specific gravity, sulfate contents $\left(\mathrm{SO}_{3}\right)$ and absorption of the used gravel were $2.65,0.07 \%, 0.57 \%$ respectively

- Water: Ordinary potable water is used throughout this work for both mixing and curing of concrete.

- Steel Reinforcement: Deformed longitudinal steel bars with nominal diameter of $8 \mathrm{~mm}$ and $4 \mathrm{~mm}$ were used in this study. Reinforcement was tested to determine the yield stress of $8 \mathrm{~mm}$ and $4 \mathrm{~mm}$ they were 400 and 350 MPa receptively

- Limestone Powder: A fine limestone powder (locally named as Al-Gubra) of northern origin with fineness $(3100$ $\mathrm{cm}^{2} / \mathrm{gm}$ ) it has been used as a filler 
for concrete production for many years. It has been found to increase workability and early strength, as well as to reduce the required compaction energy. The increased strength is found particularly when the powder is finer than the Portland cement (ECOSERVE Network 2004) The cement in SCC mixes is generally partially replaced by fillers like lime stone powder in order to improve certain properties such as

$>\begin{aligned} & \text { Avoiding excessive heat } \\ & \text { generation. }\end{aligned}$
$>\begin{aligned} & \text { Enhancing } \\ & \text { cohesiveness. }\end{aligned}$

\section{Enhancing segregation} resistance.

$>$ Increasing the amount of powder (cement + filler), so it becomes more economical than using cement alone.

Superplasticizer (Degussa construction chemicals 2002) To produce SCC, a superplasticizer known as (High Water Reducing Agent) based on polycarboxylic ether is used; it has the trademark Glenium 51. Glenium 51 is free from chlorides and complies with ASTM C494, types A and F. It is compatible with all Portland cements that meet recognized international standards. Table (4) shows the typical properties of Glenium 51 .

\begin{tabular}{|c|c|c|c|}
\hline Compound Composition & Chemical Formula & $\begin{array}{c}\text { Percent of cement } \\
\text { weight }\end{array}$ & $\begin{array}{c}\text { Limit of Iraqi specification } \\
\text { No.5/1984 }\end{array}$ \\
\hline Lime & $\mathrm{CaO}$ & 61.67 & - \\
\hline Silica & $\mathrm{SiO}_{2}$ & 20.69 & - \\
\hline Alumina & $\mathrm{Al}_{2} \mathrm{O}_{3}$ & 5.20 & - \\
\hline Iron Oxide & $\mathrm{Fe} 2 \mathrm{O} 3$ & 4.61 & - \\
\hline Magnesia & $\mathrm{MgO}$ & 2.43 & $<5$ \\
\hline Sulfate & $\mathrm{SO}_{3}$ & 2.21 & $<2.8$ \\
\hline Loss on Ignition & L.O.I. & 3.31 & $<4$ \\
\hline Insoluble Residue & I.R. & 0.5 & $<1.5$ \\
\hline Lime Saturation Factor & L.S.F & 0.90 & $0.66-1.02$ \\
\hline \multicolumn{4}{|c|}{ Main Compounds (Bogue's Equation) Percentage by Weight of Cement } \\
\hline Tricalcium Silicate & $\mathrm{C}_{3} \mathrm{~S}$ & & 38.55 \\
\hline Dicalcium Silicate & $\mathrm{C}_{2} \mathrm{~S}$ & & 33.15 \\
\hline Tricalcium Aluminate & $\mathrm{C}_{3} \mathrm{~A}$ & & 7.12 \\
\hline Tetracalcium Alumina Ferrite & $\mathrm{C} 4 \mathrm{AF}$ & & 10.73 \\
\hline
\end{tabular}

Table (3): Chemical Composition of Cement.

\begin{tabular}{|c|c|c|}
\hline Physical properties & Test Results & Limit of Iraqi specification No. 5/1984 \\
\hline $\begin{array}{c}\text { Specific Surface area (Blaine Method, } \\
\left.\mathbf{c m}^{2} / \mathbf{g m}\right)\end{array}$ & 3043 & $\geq 2300.0$ \\
\hline $\begin{array}{c}\text { Setting time (Vicats Method) } \\
\text { Initial Setting time, hrs. : min } \\
\text { Final Setting time, hrs. : min }\end{array}$ & 174 & $>45 \mathrm{~min}$ \\
\hline Compressive strength of mortar \\
2 days (MPa) & $3: 54$ & $\leq 10: 00 \mathrm{hr}$ \\
$\mathbf{7}$ days (MPa) & 21.61 & $\geq 15$ \\
\hline
\end{tabular}

Table (4): Physical Properties of the Cement Used in this Work. 


\begin{tabular}{|c|c|c|}
\hline \multirow{2}{*}{ No. } & Main action & Concrete super plasticizer \\
& & Light brown \\
\hline 1 & Color & 6.6 \\
\hline 2 & pH. Value & Viscous liquid \\
\hline 3 & Form & Hardening \\
\hline 4 & Subsidiary effect & 1.1 at $20^{\circ} \mathbf{C}$ \\
\hline 5 & Relative density & $128 \pm 30$ cps at $20^{\circ} \mathbf{C}$ \\
\hline 6 & Viscosity & Not classified as dangerous \\
\hline 7 & Transport & No hazard label required \\
\hline 8 & Labeling & \\
\hline
\end{tabular}

Table (5): Typical properties of Glenium 51 (Degussa construction chemicals 2002)

Mix proportioning is more critical for SCC than for NSC and HSC. Many trials are carried out on mixes incorporating superplasticizer by increasing the dosage of the admixture gradually, adjusting the w/c ratio to ensure the self-compact ability (Al-Jadiri, R.S.F., 2008). Table (5) indicates the mix proportion of SCC mixes. For each concrete mix, three standard cube specimens $(150 \times 150 \times 150) \mathrm{mm}$ are taken, they were tested at 28 days of age, the test results of fresh concrete properties are shown in Table (6) these results are within the acceptable criteria for SCC given by ACI committee-363 (American concrete institute, Detroit., 1998) and indicate excellent deformability without blocking.

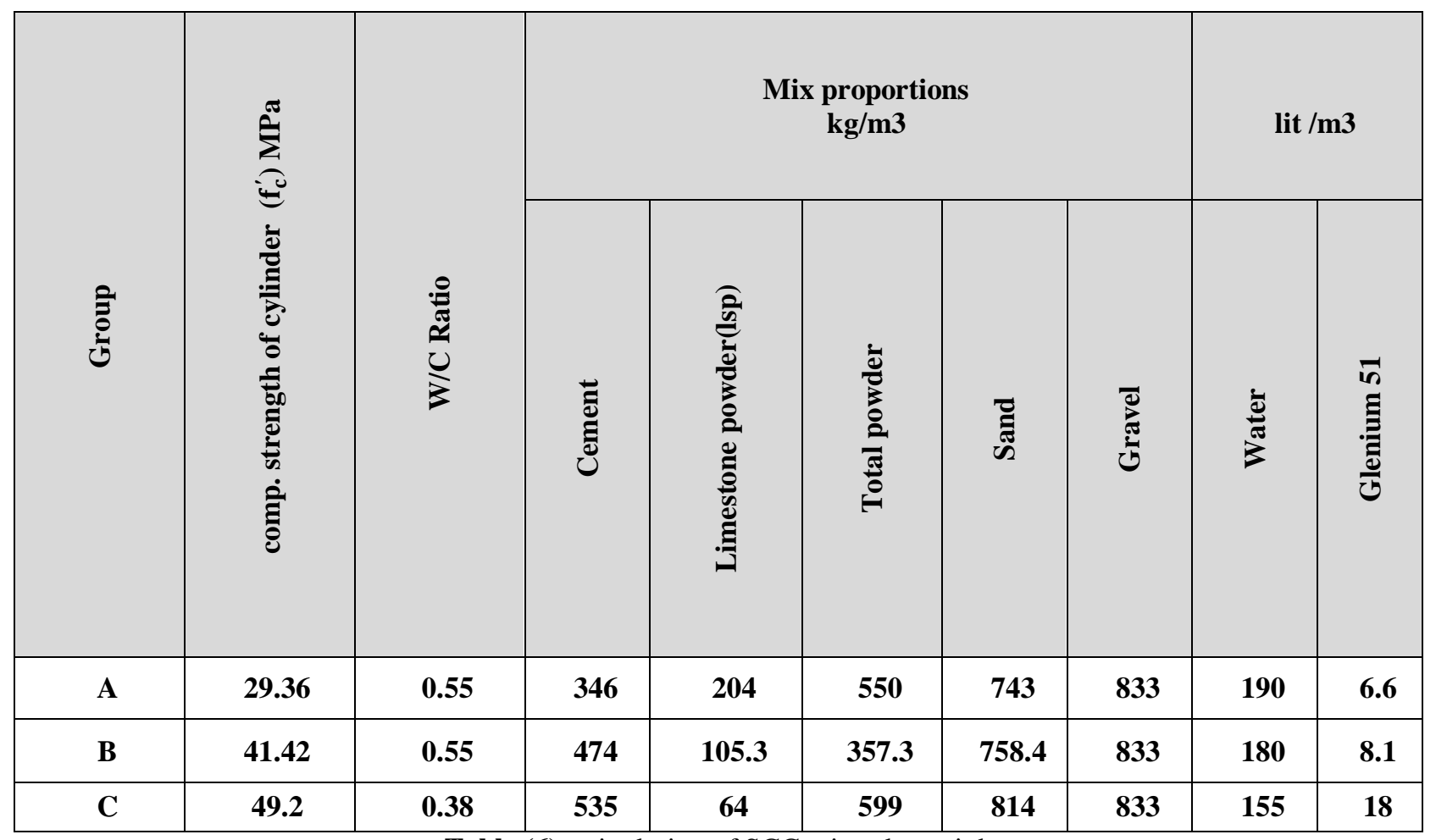

Table (6): mix design of SCC mixes by weight. 


\begin{tabular}{|c|c|c|c|c|c|}
\hline Mix symbol & $\begin{array}{l}\text { Slump flow } \\
(\mathbf{m m})\end{array}$ & $\begin{array}{l}\text { T50 } \\
\text { Sec. }\end{array}$ & $\begin{array}{c}\text { L-box } \\
\text { (H2/H1) }\end{array}$ & $\begin{array}{l}\text { T20 } \\
\text { Sec. }\end{array}$ & $\begin{array}{l}\text { T40 } \\
\text { Sec. }\end{array}$ \\
\hline A & 750 & 2.6 & 0.96 & 1.8 & 3.5 \\
\hline B & 715 & 3.8 & 0.90 & 2.1 & 3.9 \\
\hline $\mathbf{C}$ & 685 & 4.9 & 0.88 & 2.3 & 4.2 \\
\hline \multicolumn{6}{|c|}{ Acceptance criteria for Self-compacted concrete (SCC) (The European Guidelines for SCC Specification ,2005) } \\
\hline \multirow{2}{*}{ NO. } & \multirow{2}{*}{ Method } & \multirow{2}{*}{ Unit } & \multicolumn{3}{|c|}{ Typical range of values } \\
\hline & & & Minimum & & Maximum \\
\hline 1 & Slump flow & $\mathbf{m m}$ & 650 & & 800 \\
\hline 2 & T50 & Sec & 2 & & 5 \\
\hline 3 & L-Box & (H2/H1) & 0.8 & & 1 \\
\hline
\end{tabular}

Table (7): Results of testing fresh SCC property in experimental work.

\section{Test procedure of Beams}

All the beams were white-washed in order to aid the observation of the crack development during the testing. Beams were tested under gradually increasing load up to failure under two point symmetric top loading in universal-Testing machine (MFL systems) at the structural laboratory of the college of the engineering, Al-Mustansiriya University as shown in Fig. (5), the tested beams were simply supported at ends over an effective span of $(50 \mathrm{~mm})$ the distance between the two point loads at the third of the clear span length. A dial gauge of $(0.01 \mathrm{~mm})$ accuracy with (30 $\mathrm{mm}$ ) capacity was fixed at the middle of the bottom of the beam to measure the mid span deflection; the test set-up is shown in Fig. ( $\varepsilon)$. Loading procedure was started by the application of single point load from the testing machine to the upper midpoint of the loading bridge. The single load was then divided equally between the two point loads that were transferred to the concrete beam through two $(\Phi 30 \mathrm{~mm})$ steel bars loaded at the end of the bridge. Beam specimens were placed in the testing machine and adjusted so that the centerline, supports, point loads and dial gauge was fixed at the correct and proper location. Loading was applied in small increments of $(4 \mathrm{KN})$. At each load stage the deflection readings at the mid span was recorded. The loading increments were applied until failure.

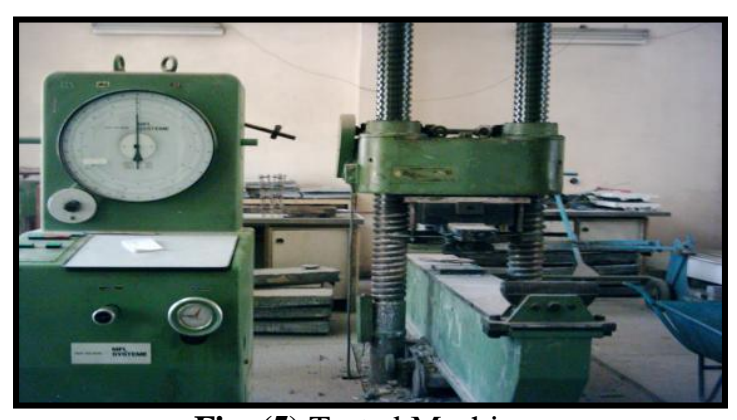

Fig. (5) Tested Machine.

\section{Shear strength of beam in Code provisions:}

$V_{n}=V_{c}+V_{s}$

$V_{c}=\frac{\sqrt{f_{c}^{\prime}}}{6} b_{w} d$

$V_{c}=\left(\sqrt{f_{c}^{\prime}}+120 \ell w V_{u} d / M_{u}\right) b_{w} d / 7$

$V_{s}=A v f_{y} d / S$

Where:-

$\mathrm{V}_{\mathrm{c}}$ and $\mathrm{V}_{\mathrm{s}}$ are shear transfer capacity of concrete and shear reinforcement respectively; $\mathrm{Mu}$ and Vud are factored moment and shear force; $\ell_{\mathrm{w}}=\mathrm{As} / \mathrm{b}_{\mathrm{w}} \mathrm{d}$ is the longitudinal bottom reinforcement ratio; $A s$ is the longitudinal 
bottom reinforcement area; $b_{w}$ is the width of the web; $d$ is the effective depth; $A_{v}$ is the vertical shear reinforcement area, $S$ is the spacing between the vertical stirrups reinforcement; $f_{c}^{\prime}$ is the compressive strength of concrete and $f_{y}$ the yield strength of shear reinforcement According to clear span to effective depth ratio $(\ln / \mathrm{d})$ the main variable in this research , Eq.(3) will be used since the shear stress at cracking will depend on the bending moment and shear force at critical section ratio $(\mathrm{Vud} / \mathrm{Mu})$ and the longitudinal steel ratio $\left(\ell_{\mathrm{w}}\right)$ that lead to reduce the shear crack and improved the ultimate strength( American concrete institute, Detroit, 2011).

\section{Results: \\ Carrying capacity of the tested beams- Load:}

The relationship between the applied load and the deflection of the tested beams is shown in Fig. (6) To Fig. (14). at every stage of loading, the deflection at mid-span is obtained by using dial gage at mid span, it can be noticed that:

- During the early stage of loading no interface slip is recorded and this continues until the applied loading is equal to first crack loading approximately, beyond the first crack loading each beam has behaved in a certain manner.

- The ultimate shear strength obtained from tests of SCC beams were compared with that obtained by using the ACI code provisions, see Table (8), by the inspection of this table it can be noted that the ultimate shear strength predicated from ACI $318 \mathrm{M}-11$ is conservative in comparison with experimental values because of the SCC will improve durability, and increased bond strength (Krieg, W 2003).

- The ultimate shear strength of SCC beams increased when the compressive strength $\left(f_{c}^{\prime}\right)$ of the SCC increased as shown Fig. (15), (16) and (17). The ultimate shear strength of SCC rectangular beams increase about 16.5\%.35.245\% and $25.665 \%$ when the compressive strength $\left(f_{c}^{\prime}\right)$ increased from (29.36 to
49.2 MPa) at clear span to effective ratio $(\ln / \mathrm{d}) 5.84,5.5$ and 5.05 respectively, The ultimate shear strength of SCC T-beams increase about $28.57 \% .10 .714 \%$ and $10.17 \%$ when the compressive strength $\left(f_{c}^{\prime}\right)$ increased from (29.36 to 49.2 $\mathrm{MPa}$ ) at clear span to effective ratio $(\ln / \mathrm{d})$ 5.84, 5.5 and 5.05 respectively, while The ultimate shear strength of SCC I-beams increase about $14.38 \% .15 .55 \%$ and $10.746 \%$ when the compressive strength $\left(f_{c}^{\prime}\right)$ increased from (29.36 to $49.2 \mathrm{MPa}$ ) at clear span to effective ratio $(\ln / \mathrm{d}) 5.84,5.5$ and 5.05 respectively see Table (9) .

- The clear span to the effective depth ratio $(\mathrm{ln} / \mathrm{d})$ has a significant influences on the ultimate shear strength of SCC beams as shown in Fig (18), (19), and (20), the ultimate shear strength of SCC rectangular beams increased about $21.58 \%, 32.9 \%$ and $32.01 \%$ when the clear span to the effective depth $(\ln / \mathrm{d})$ decreased from (5.84 to 5.05) at compressive strength $\left(f_{c}^{\prime}\right)$ 29.36, 41.42 and 49.2 $\mathrm{MPa}$ respectively, the ultimate shear strength of SCC T-beams increased about $40.47 \%, 34.73 \%$ and $20.37 \%$ when the clear span to the effective depth $(\ln / \mathrm{d})$ decreased from (5.84 to 5.05) at compressive strength $\left(f_{c}^{\prime}\right)$ 29.36, 41.42 and $49.2 \mathrm{MPa}$ respectively, while the ultimate shear strength of SCC I-beams increased about 44.72\%,45.19\%and $40.13 \%$ when the clear span to the effective depth $(\ln / \mathrm{d})$ decreased from (5.84 to 5.05) at compressive strength $\left(f_{c}^{\prime}\right)$ $29.36,41.42$ and $49.2 \mathrm{MPa}$ respectively as shown in Table (10)

\section{Failure mode:}

As was expected, all the tested beams failed in shear as shown in Fig. (21) and Fig. (22), the diagonal cracks form independently. The beams remain stable after such cracking. Further increase in shear force causes the diagonal crack to penetrate into the compression zone at the loading point, until eventually crushing failure of concrete occurs there (bdel-Razzak, A.A., 2001). 


\begin{tabular}{|c|c|c|c|c|}
\hline Group & Beam & $\begin{array}{c}\text { Ultimate shear strength } \\
\text { (Vu kN)tested }\end{array}$ & $\begin{array}{c}\text { Nominal shear strength } \\
(\text { Vn kN) ACI }\end{array}$ & $\begin{array}{c}\text { Vu tested/Vn } \mathrm{ACl} \\
\text { ratio }\end{array}$ \\
\hline \multirow{9}{*}{$\begin{array}{l}\text { Rectangular } \\
\text { Section }\end{array}$} & A 1 & 46.94 & 34.60 & 1.356 \\
\hline & A 2 & 50.78 & 34.60 & 1.467 \\
\hline & A 3 & 57.07 & 34.60 & 1.649 \\
\hline & B 1 & 51.68 & 36.181 & 1.428 \\
\hline & B 2 & 64.35 & 36.181 & 1.778 \\
\hline & B 3 & 68.68 & 36.181 & 1.898 \\
\hline & C 1 & 54.32 & 37.391 & 1.452 \\
\hline & C 2 & 66.36 & 37.391 & 1.774 \\
\hline & C 3 & 71.71 & 37.391 & 1.917 \\
\hline \multirow{9}{*}{ T-Section } & A 10 & 42 & 29.30 & 1.433 \\
\hline & A 20 & 56 & 29.30 & 1.911 \\
\hline & A 30 & 59 & 29.30 & 2.013 \\
\hline & B 10 & 47.5 & 30.90 & 1.537 \\
\hline & B 20 & 60 & 30.90 & 1.941 \\
\hline & B 30 & 64 & 30.90 & 2.071 \\
\hline & C 10 & 54 & 31.70 & 1.703 \\
\hline & C 20 & 62 & 31.70 & 1.955 \\
\hline & C 30 & 65 & 31.70 & 2.050 \\
\hline \multirow{9}{*}{ I-Section } & A 100 & 56.05 & 31.719 & 1.767 \\
\hline & A 200 & 73.99 & 31.719 & 2.332 \\
\hline & A 300 & 81.13 & 31.719 & 2.557 \\
\hline & B 100 & 60.47 & 33.725 & 1.793 \\
\hline & B 200 & 82.75 & 33.725 & 2.453 \\
\hline & B 300 & 87.8 & 33.275 & 2.638 \\
\hline & C 100 & 64.11 & 34.866 & 1.838 \\
\hline & C 200 & 85.5 & 34.866 & 2.452 \\
\hline & C 300 & 89.85 & 34.866 & 2.577 \\
\hline
\end{tabular}

Table (8) comparisons of tested results.

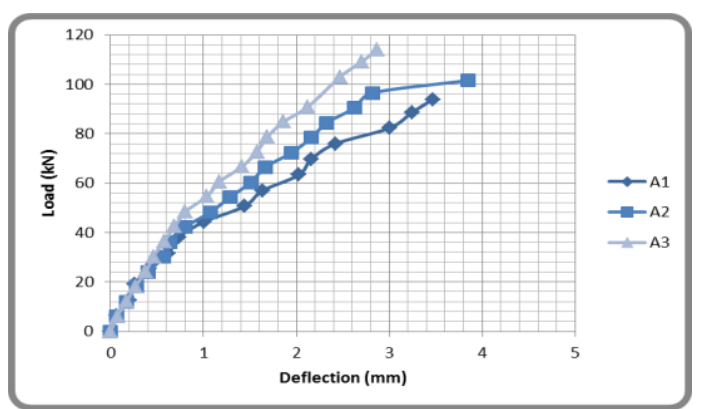

Fig. (6): Load -deflection curve for SCC rectangular beams at compressive strength $\left(f_{c}^{\prime}\right)$ $=29.36 \mathrm{Mpa}$.

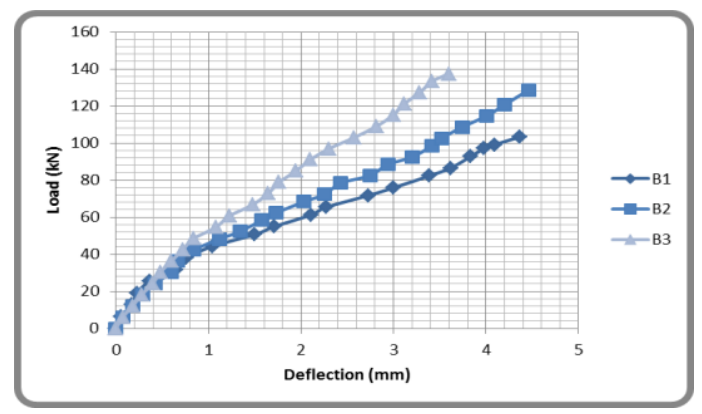

Fig. (7): Load -deflection curve for SCC rectangular beams at compressive strength $\left(f_{c}^{\prime}\right)$ $=41.42 \mathrm{Mpa}$. 


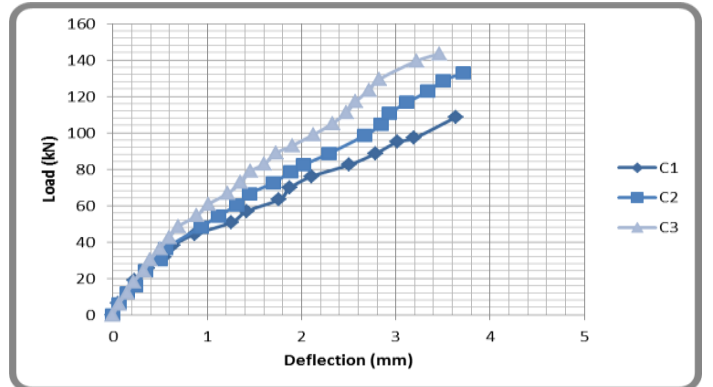

Fig. (8): Load -deflection curve for SCC rectangular beams at compressive strength $\left(f_{c}^{\prime}\right)$ $=49.2 \mathrm{Mpa}$.

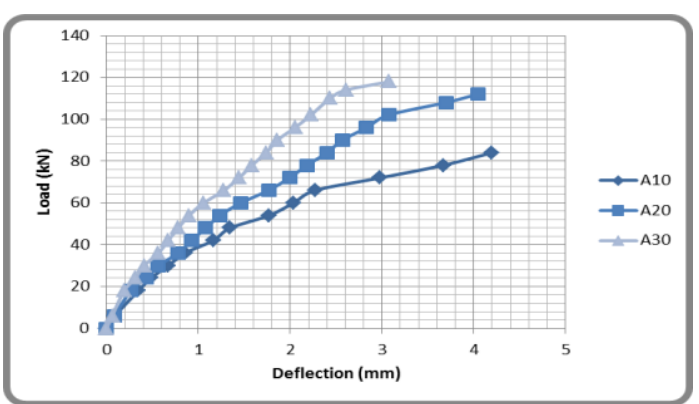

Fig. (9) Load -deflection curve for SCC T-section beams at compressive strength $\left(f_{c}^{\prime}\right)=29.36 \mathrm{Mpa}$.

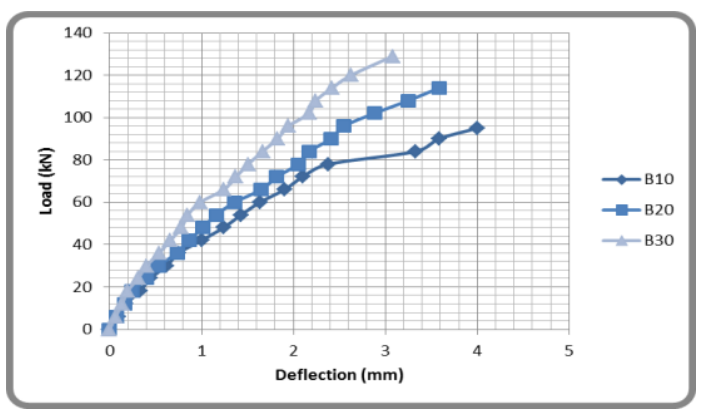

Fig. (10): Load -deflection curve for SCC Tsection beams at compressive strength $\left(f_{c}^{\prime}\right)=41.42$ Mpa.

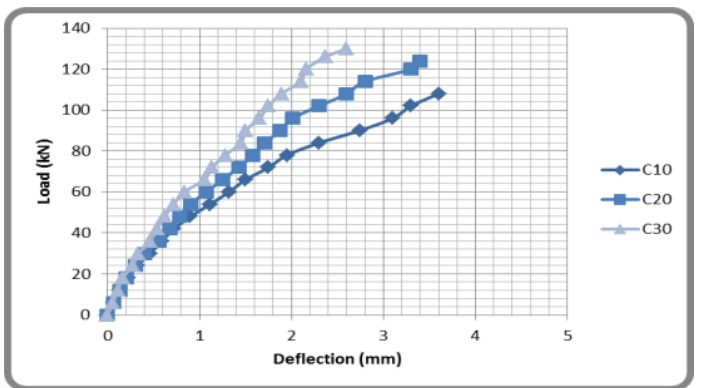

Fig. (11): Load -deflection curve for SCC Tsection beams at compressive strength $\left(f_{c}^{\prime}\right)=49.2$ Mpa.

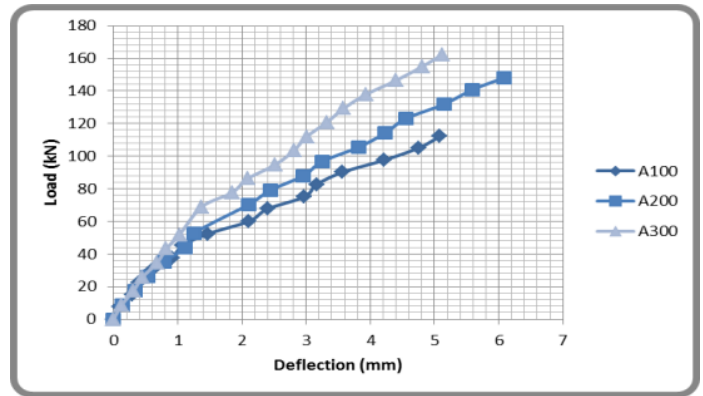

Fig. (12): Load -deflection curve for SCC Isection beams at compressive strength $\left(f_{c}^{\prime}\right)=29.36$ Mpa.

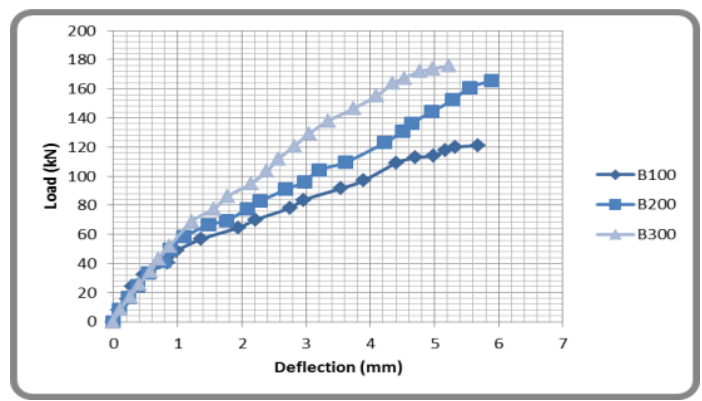

Fig. (13): Load -deflection curve for SCC Isection beams at compressive strength $\left(f_{c}^{\prime}\right)=41.42$ Mpa.

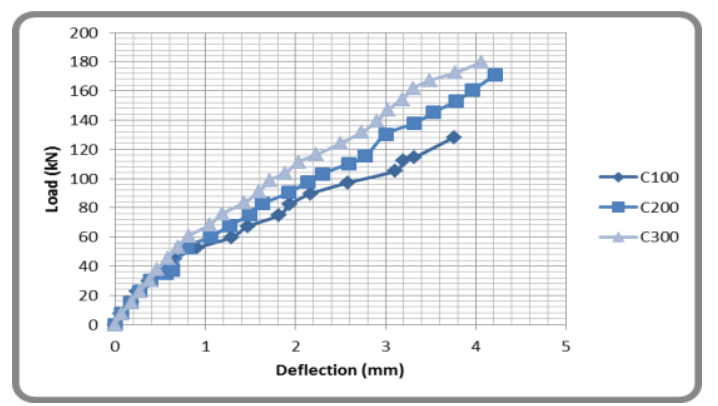

Fig. (14): Load -deflection curve for SCC Isection beams at compressive strength $\left(f_{c}^{\prime}\right)=49.2$ Mpa.

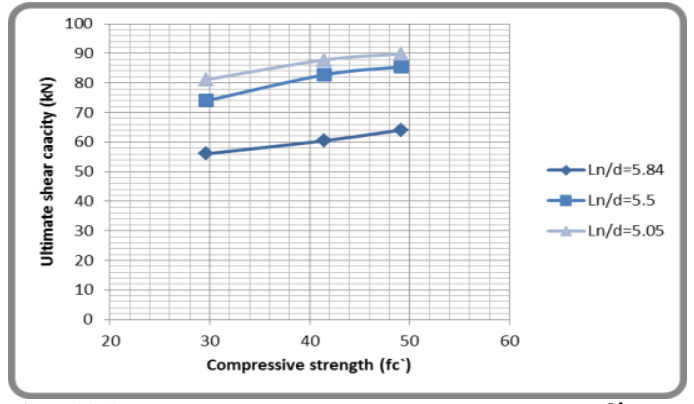

Fig. (15): Effect of compressive strength $\left(f_{c}^{\prime}\right)$ for SCC rectangular beams on the ultimate strength. 


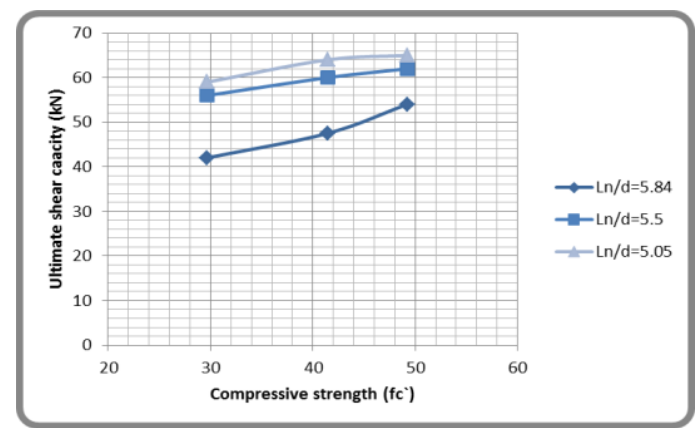

Fig. (16): Effect of compressive strength $\left(f_{c}^{\prime}\right)$ for SCC T-section beams on the ultimate shear strength.

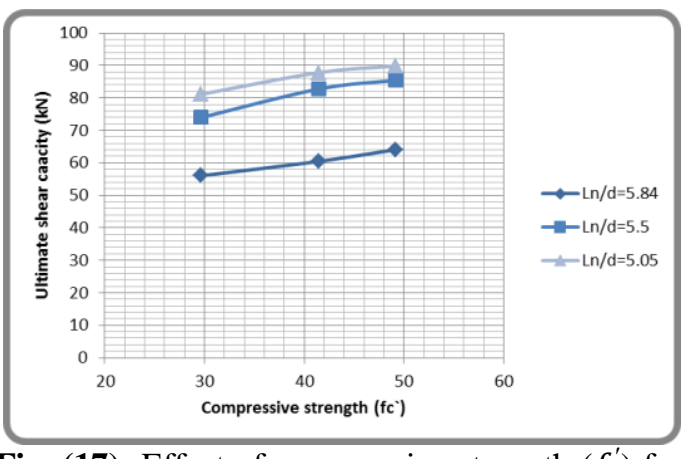

Fig. (17): Effect of compressive strength $\left(f_{c}^{\prime}\right)$ for SCC I-section beams on the ultimate strength.

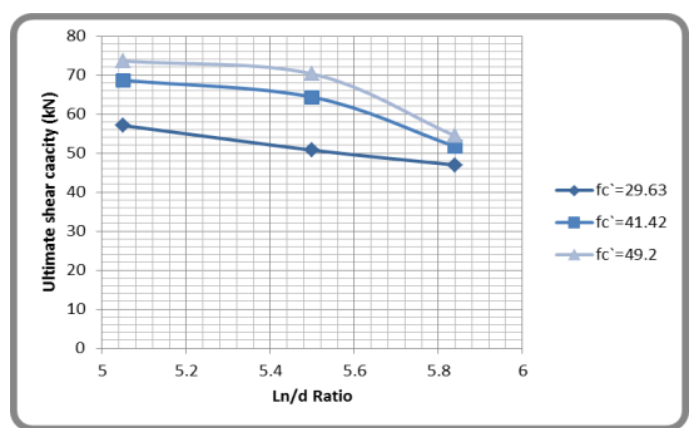

Fig. (18): Effect of clear span to the effective depth ratio $(\ln / \mathrm{d})$ on the ultimate shear strength for rectangular section.

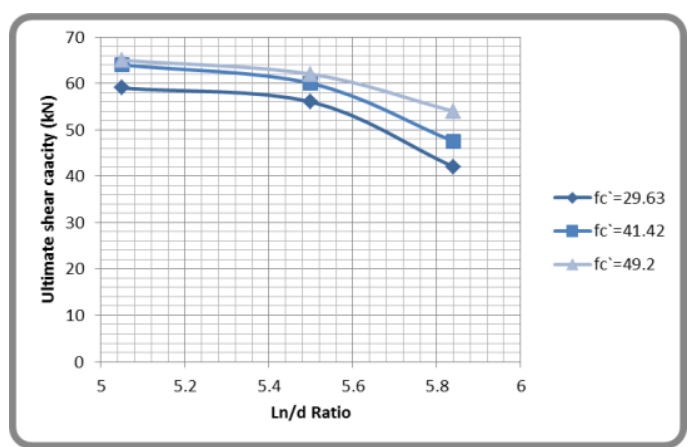

Fig. (19): Effect of clear span to the effective depth ratio $(\ln / \mathrm{d})$ on the ultimate shear strength for $\mathrm{T}$ - section.

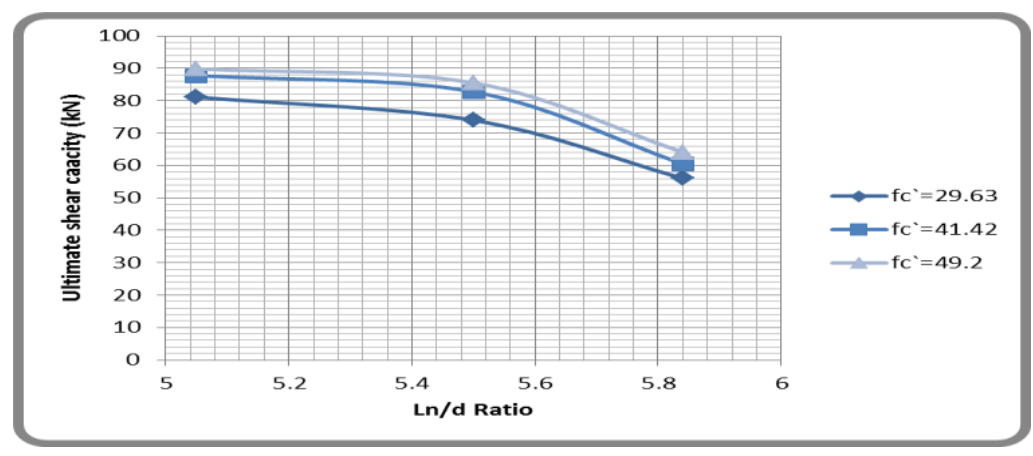

Fig. (20) Effect of clear span to the effective depth ratio (ln/d) on the ultimate shear strength for I- section. 


\begin{tabular}{|c|c|c|c|c|c|}
\hline Shapes & $\begin{array}{c}\text { Clear span to effective } \\
\text { depth ratio }(\ln / \mathbf{d})\end{array}$ & Beam & Comp. strength $\left(\mathbf{f}_{\mathrm{c}}^{\prime}\right) \mathrm{MPa}$ & $\begin{array}{l}\text { Ultimate shear } \\
\text { capacity }(\mathbf{V u}) \mathrm{kN}\end{array}$ & Percentage of increased \% \\
\hline \multirow{9}{*}{$\begin{array}{l}\text { Rectangular } \\
\text { Sections }\end{array}$} & 5.84 & $\mathrm{~A} 1$ & 29.39 & 46.94 & ---- \\
\hline & 5.84 & B1 & 41.4 & 51.687 & 10.123 \\
\hline & 5.84 & $\mathrm{C} 1$ & 49.2 & 54.32 & 16.50 \\
\hline & 5.50 & $\mathrm{~A} 2$ & 29.39 & 50.779 & ---- \\
\hline & 5.50 & B2 & 41.4 & 64.35 & 26.725 \\
\hline & 5.50 & $\mathrm{C} 2$ & 49.2 & 68.686 & 35.245 \\
\hline & 5.05 & $\mathrm{~A} 3$ & 29.39 & 57.070 & --- \\
\hline & 5.05 & B3 & 41.4 & 68.686 & 20.354 \\
\hline & 5.05 & $\mathrm{C} 3$ & 49.2 & 71.717 & 25.665 \\
\hline \multirow{9}{*}{ T-Sections } & 5.84 & A10 & 29.39 & 42.0 & ---- \\
\hline & 5.84 & B10 & 41.4 & 47.5 & 13.09 \\
\hline & 5.84 & $\mathrm{C} 10$ & 49.2 & 54.0 & 28.571 \\
\hline & 5.50 & A20 & 29.39 & 56.0 & --- \\
\hline & 5.50 & $\mathrm{~B} 20$ & 41.4 & 60.0 & 6.666 \\
\hline & 5.50 & $\mathrm{C} 20$ & 49.2 & 62.0 & 10.7142 \\
\hline & 5.05 & A30 & 29.39 & 59.0 & ------ \\
\hline & 5.05 & B30 & 41.4 & 64.0 & 8.475 \\
\hline & 5.05 & $\mathrm{C} 30$ & 49.2 & 65.0 & 10.170 \\
\hline \multirow{9}{*}{ I- Sections } & 5.84 & A100 & 29.39 & 56.05 & --- \\
\hline & 5.84 & B100 & 41.4 & 60.47 & 7.885 \\
\hline & 5.84 & C100 & 49.2 & 64.11 & 14.380 \\
\hline & 5.50 & A200 & 29.39 & 73.99 & 17.000 \\
\hline & 5.50 & B200 & 41.4 & 82.75 & 11.8394 \\
\hline & 5.50 & C200 & 49.2 & 85.50 & 15.556 \\
\hline & 5.05 & A300 & 29.39 & 81.131 & ---- \\
\hline & 5.05 & B300 & 41.4 & 87.80 & 8.220 \\
\hline & 5.05 & $\mathrm{C} 300$ & 49.2 & 89.85 & 10.746 \\
\hline
\end{tabular}

Table (9) effect of compressive strength $\left(f_{c}^{\prime}\right)$ ) on the percentage increased in the ultimate shear strength of tested beams.

\begin{tabular}{|c|c|c|c|c|c|}
\hline Shapes & $\begin{array}{c}\text { Clear span to } \\
\text { effective depth ratio } \\
(\ln / \mathbf{d})\end{array}$ & Beam & $\begin{array}{c}\text { Comp. strength }\left(\mathbf{f}_{\mathbf{c}}^{\prime}\right) \\
\mathrm{MPa}\end{array}$ & $\begin{array}{l}\text { Ultimate shear } \\
\text { capacity }(\mathrm{Vu}) \mathrm{kN}\end{array}$ & $\begin{array}{c}\text { Percentage of increased } \\
\%\end{array}$ \\
\hline \multirow{9}{*}{ Rectangular Sections } & 5.84 & $\mathrm{~A} 1$ & 29.39 & 46.94 & --.-- \\
\hline & 5.50 & $\mathrm{~A} 2$ & 29.39 & 50.78 & 8.18 \\
\hline & 5.05 & A3 & 29.39 & 57.07 & 21.58 \\
\hline & 5.84 & B1 & 41.4 & 51.68 & ----- \\
\hline & 5.50 & B2 & 41.4 & 64.35 & 24.51 \\
\hline & 5.05 & B3 & 41.4 & 68.68 & 32.90 \\
\hline & 5.84 & $\mathrm{C} 1$ & 49.2 & 54.32 & ----- \\
\hline & 5.50 & $\mathrm{C} 2$ & 49.2 & 66.36 & 22.165 \\
\hline & 5.05 & $\mathrm{C} 3$ & 49.2 & 71.71 & 32.01 \\
\hline \multirow{9}{*}{ T-Sections } & 5.84 & A10 & 29.39 & 42.0 & 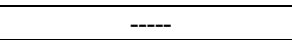 \\
\hline & 5.50 & A20 & 29.39 & 56.0 & 33.33 \\
\hline & 5.05 & $\mathrm{~A} 30$ & 29.39 & 59.0 & 40.47 \\
\hline & 5.84 & B10 & 41.4 & 47.5 & ---- \\
\hline & 5.50 & $\mathrm{~B} 20$ & 41.4 & 60.0 & 26.31 \\
\hline & 5.05 & $\mathrm{~B} 30$ & 41.4 & 64.0 & 34.73 \\
\hline & 5.84 & C10 & 49.2 & 54.0 & ---- \\
\hline & 5.50 & $\mathrm{C} 20$ & 49.2 & 62.0 & 14.81 \\
\hline & 5.05 & $\mathrm{C} 30$ & 49.2 & 65.0 & 20.37 \\
\hline \multirow{9}{*}{ I- Sections } & 5.84 & A100 & 29.39 & 56.05 & ----- \\
\hline & 5.50 & A200 & 29.39 & 73.99 & 32.0 \\
\hline & 5.05 & $\mathrm{~A} 300$ & 29.39 & 81.12 & 44.72 \\
\hline & 5.84 & B100 & 41.4 & 60.47 & ---- \\
\hline & 5.50 & B200 & 41.4 & 82.75 & 36.38 \\
\hline & 5.05 & B300 & 41.4 & 87.80 & 45.19 \\
\hline & 5.84 & $\mathrm{C} 100$ & 49.2 & 64.11 & - --- \\
\hline & 5.50 & C200 & 49.2 & 85.5 & 33.36 \\
\hline & 5.05 & C300 & 49.2 & 89.85 & 40.15 \\
\hline
\end{tabular}

Table (10) effect of clear span to effective depth ratio $(L n / d)$ ) on the percentage increased in the ultimate shear strength of tested beams. 


\section{Conclusions}

Based on the tested results of this experimental investigation for evaluation of shear strength of SCC beams, the following conclusions are drawn:

- The ultimate shear strength predicated from ACI $318 \mathrm{M}-11$ is a conservative prediction than the experimental values for the SCC beams. The ultimate shear strength obtained from tested of SCC beams were compared with that obtained by using the ACI code provisions.

- The ultimate shear strength of SCC rectangular beams increase about $16.5 \% 35.245 \%$ and $25.665 \%$ when the compressive strength $\left(f_{c}^{\prime}\right)$ increased from (29.36 to $49.2 \mathrm{MPa}$ ) at clear span to effective ratio $(\ln / \mathrm{d}) 5.84,5.5$ and 5.05 respectively

- The ultimate shear strength of SCC Tbeams increase about $28.57 \%, 10.714 \%$, and $10.17 \%$ when the compressive strength $\left(f_{c}^{\prime}\right)$ increased from (29.36 to $49.2 \mathrm{MPa}$ ) at clear span to effective ratio $(\ln / \mathrm{d}) 5.84,5.5$ and 5.05 respectively,

- The ultimate shear strength of SCC Ibeams increase about $14.38 \% .15 .55 \%$ and $10.746 \%$ when the compressive strength $\left(f_{c}^{\prime}\right)$ increased from (29.36 to $49.2 \mathrm{MPa}$ ) at clear span to effective ratio $(\ln / \mathrm{d}) 5.84$, 5.5 and 5.05 respectively.

- The ultimate shear strength of SCC rectangular beams increased about $21.58 \%, 32.9 \%$ and $32.01 \%$ when the clear span to the effective depth $(\ln / \mathrm{d})$ decreased from (5.84 to 5.05) at compressive strength $\left(f_{c}^{\prime}\right) 29.36,41.42$ and 49.2 MPa respectively.

- The ultimate shear strength of SCC Tbeams increased about $40.47 \%, 34.73 \%$, and $20.37 \%$ when the clear span to the effective depth $(\ln / \mathrm{d})$ decreased from (5.84 to 5.05) at compressive strength $\left(f_{c}^{\prime}\right)$ 29.36, 41.42 and 49.2 MPa respectively.

- The ultimate shear strength of SCC Ibeams increased about $44.72 \%, 45.19 \%$ and $40.13 \%$ when the clear span to the effective depth $(\ln / \mathrm{d})$ decreased from (5.84 to 5.05) at compressive strength $\left(f_{c}^{\prime}\right)$ 29.36, 41.42 and 49.2 MPa respectively .
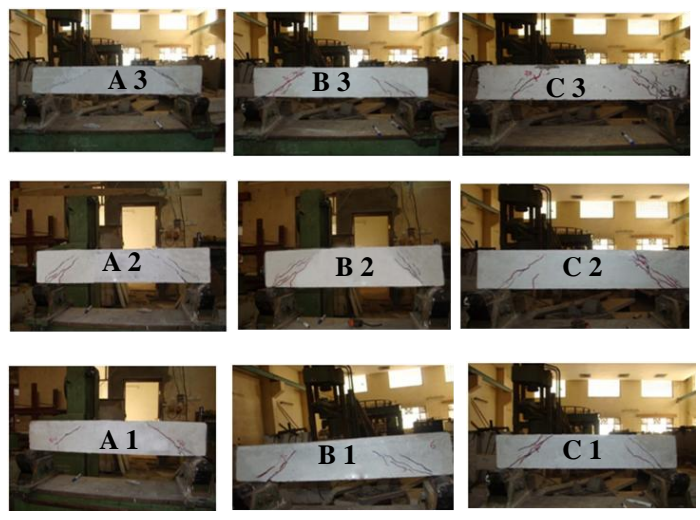

Fig (21): Crack pattern of SCC Rectangular beams.

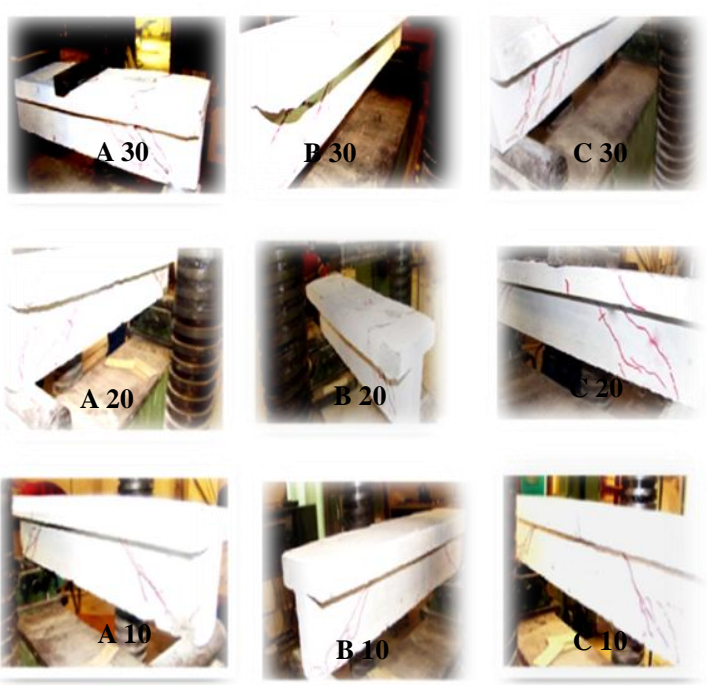

Fig (21): Crack pattern of SCCT-section beams.

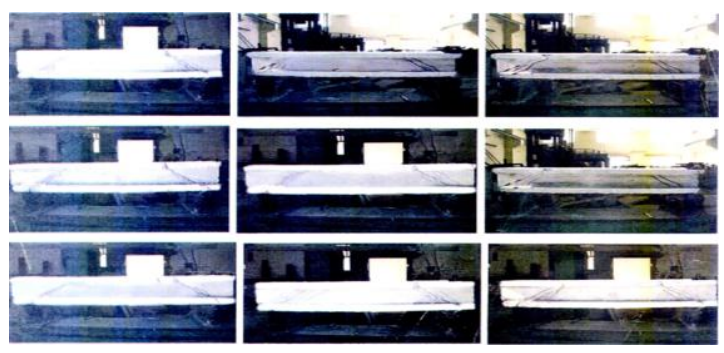

Fig (22): Crack pattern of SCC I-section beams.

\section{References}

ACI Committee 363 "Guide to Quality Control and Testing of High Strength Concrete (ACI- 363, 2R-98)", American Concrete Institute, Detroit, (1998).

Al-Jadiri, R.S.F., "A Method for Proportioning Self-Compacting Concrete Based. M.Sc. 
Thesis, University of Al- Mustansiriya. Baghdada (2008).

bdel-Razzak A.A., "The Effect of Low Shear Span Ratio on the Shear Strength of RC Beams", M.Sc. Thesis, University of Technology, Baghdad, (2001).

"Baseline Report for the Aggregate and Concrete Industries in Europe", ECOSERVE Network, Cluster 3: Aggregate and Concrete Production, June (2004), $68 \mathrm{PP}$.

Bin MUDA, M.F., "The Properties and Flexural Behavior OF self-Compacting Concrete Using Rice Husk Ash and Admixture", M.Sc. Thesis, University of Technology. Malaysia, (2009).

"ACI Committee 318" Building Code Requirements for Structural Concrete and Commentary (ACI 318M-11)",
American Concrete Institute, Detroit, (2011).

"Glenium 51", Degussa construction chemicals. 06\MBT-Me Revised 06 I(2002).

Krieg, W. " Self Compacting Concrete : Definition, Development, and Applications", A technical Paper Presented in the Meeting of the ACI, Saudi Arbia Chapter, Eastern Province, October, (2003).

The European Guidelines for Self-Compacting Concrete Specification", production and use, May (2005), www.efca.info or www.efnarc.org, pp.68.

المواصفة العراقية رقم ه "الاسمنت البورتلاندي، الجهاز

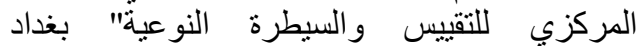

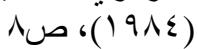

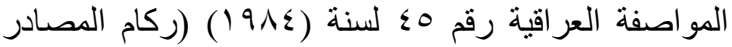

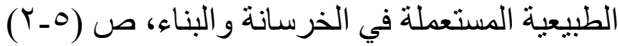

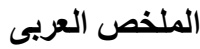

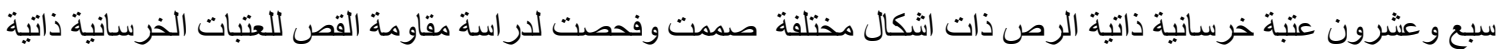

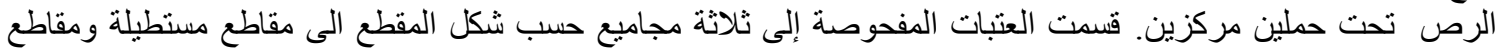

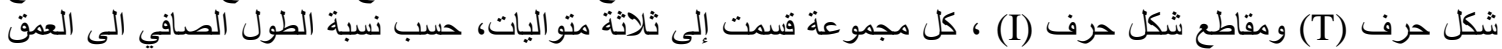

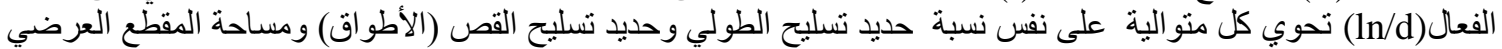

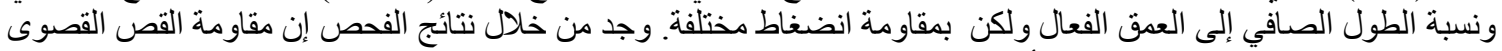

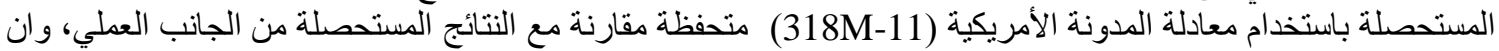

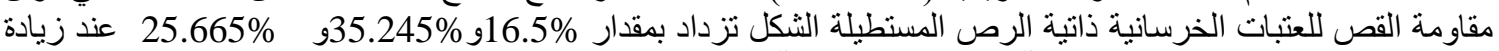

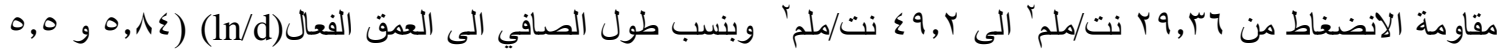

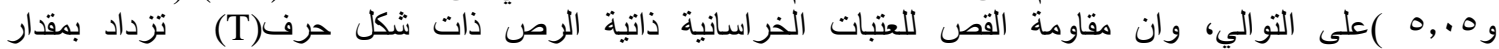

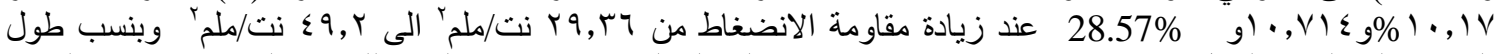

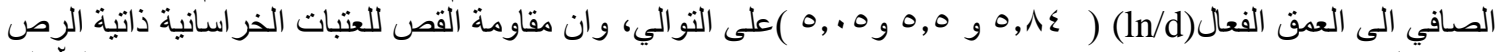

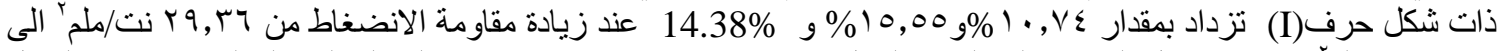

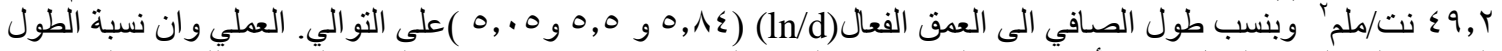

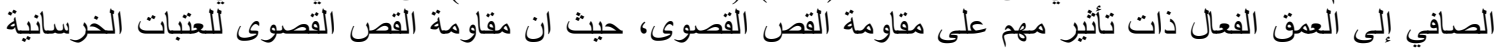

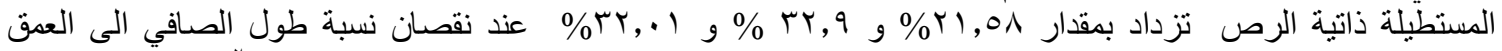

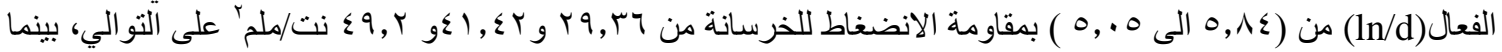

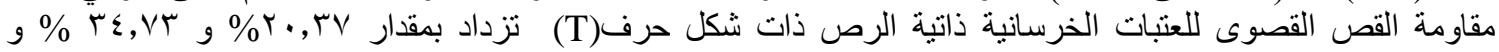

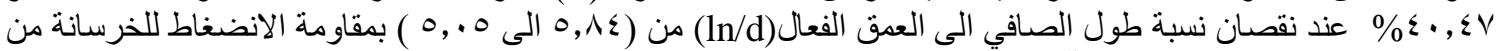

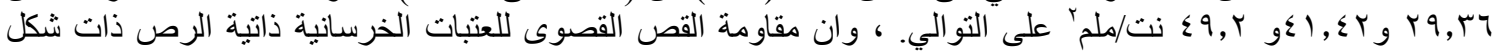

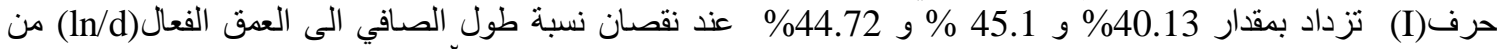

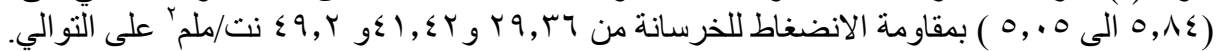

